\title{
Temporal and spatial variability of the surface mass balance in Dronning Maud Land, Antarctica, as derived from automatic weather stations
}

\author{
Garleen H. ReijMer, Mighiel R. van den BROEKE \\ Institute for Marine and Atmospheric Research, P.O. Box 80.005, Utrecht University, Princetonplein 5, 3508 TA Utrecht, The Netherlands \\ E-mail: ch.reijmer@phys.uu.nl
}

\begin{abstract}
Measurements of changes in surface height carried out with sonic altimeters mounted on automatic weather stations in Dronning Maud Land (DML) and on Berkner Island, Antarctica, are used to derive the surface mass balance. The surface mass balance is positive at all sites, i.e. accumulation outweighs ablation. The spatial and temporal variability in accumulation is high. Accumulation occurs in numerous small events and a few large events per year. The larger events contribute more to the annual accumulation than the small events; $\sim 50 \%$ of all accumulation is contributed by $10-25 \%$ of all events. The accumulation generally decreases with increasing distance from the coast and elevation. Annual averaged values range from $\sim 375 \pm 59 \mathrm{~mm}$ w.e. $\mathrm{a}^{-1}$ near the coast to $\sim 33 \pm 25 \mathrm{~mm}$ w.e. $\mathrm{a}^{-1}$ on the Antarctic plateau and are in good agreement with long-term averaged annual accumulation rates obtained from snow pits and firn cores. The records show seasonal dependency of the amount of accumulation, with a maximum in winter in the coastal and escarpment region of DML and in summer on Berkner Island and on the plateau. The seasonal cycles are significant on Berkner Island, and in the coastal area and part of the escarpment region.
\end{abstract}

\section{INTRODUGTION}

Data pertaining to past climate and the state of the atmosphere are stored in the ice of the Antarctic and Greenland ice sheets. In recent decades, several deep ice cores have been drilled to gain access to these climate records (e.g. the Vostok ice core, Antarctica (Petit and others, 1999), and the Greenland Ice Core Project (GRIP Members, 1993)). The main objective of the European Project for Ice Coring in Antarctica (EPICA) is to construct a very long ( $>500 \mathrm{kyr}$ ) climate record for Antarctica at low temporal resolution in addition to a shorter record with a high temporal resolution. The two EPICA cores are drilled at Dome C (Wolff and others 1999) and Kohnen station (Oerter and others, 2000) (Fig. 1). To identify the optimal site for the deep drilling at Kohnen station, several pre-site surveys were carried out in Dronning Maud Land (DML). These consisted of detailed mapping of the surface and bedrock topography (Steinhage and others, 1999) and drilling of shallow and mediumlength ice cores, to study the spatial distribution of the surface mass balance (Isaksson and others, 1999; Karlöf and others, 2000; Oerter and others, 2000). Furthermore, the meteorological conditions in DML were studied by means of automatic weather stations (AWSs) (Reijmer and van den Broeke, 2001; Reijmer and Oerlemans, 2002) and atmospheric modelling (van den Broeke and others, 2002; Van Lipzig and others, 2002a, b).

The climate recorded in ice cores is determined by the conditions prevailing when snowfall occurs. However, these need not be representative of the mean climate conditions at that point (Noone and others, 1999; Reijmer and van den
Broeke, 2001). Factors such as seasonality of the snowfall and changes in moisture source may systematically bias the ice-core record (Jouzel and others, 1997). Van Lipzig and others (2002a) show that the year-to-year variability in the temperature records derived from ice cores is overestimated owing to variations in the seasonality of the snowfall. A thorough understanding of the spatial and temporal patterns of the surface mass balance as well as the meteorological conditions in which snowfall occurs is therefore indispensable when interpreting climate signals obtained from ice cores (Jouzel and others, 1997; Werner and others, 2000; Van Lipzig and others 2002b).

We present data from several AWSs located in DML and on Berkner Island, Antarctica (Fig. 1). The AWSs measure on an hourly basis and produce detailed time series of, amongst others, the changes in surface height, a measure for the surface mass balance. The surface mass balance is defined as the total gain or loss of mass of snow/ice at the surface in a certain amount of time. Accumulation is the total mass gain at the surface due to snowfall or snowdrift deposition. Ablation is the total mass loss at the surface due to melting, evaporation or wind erosion. The changes in surface height are measured with sonic altimeters. The high temporal resolution and the straightforward interpretation of the sonic altimeter measurements are an advantage over other methods such as ice cores and snow pits, stakes and thermistors. Ice cores and snow pits only register accumulation, and the accumulation rates obtained are usually long-term annual averages (Karlöf and others, 2000; Oerter and others, 2000). The temporal resolution of stake measurements ranges between weeks and years (Jonsson, 1990; 


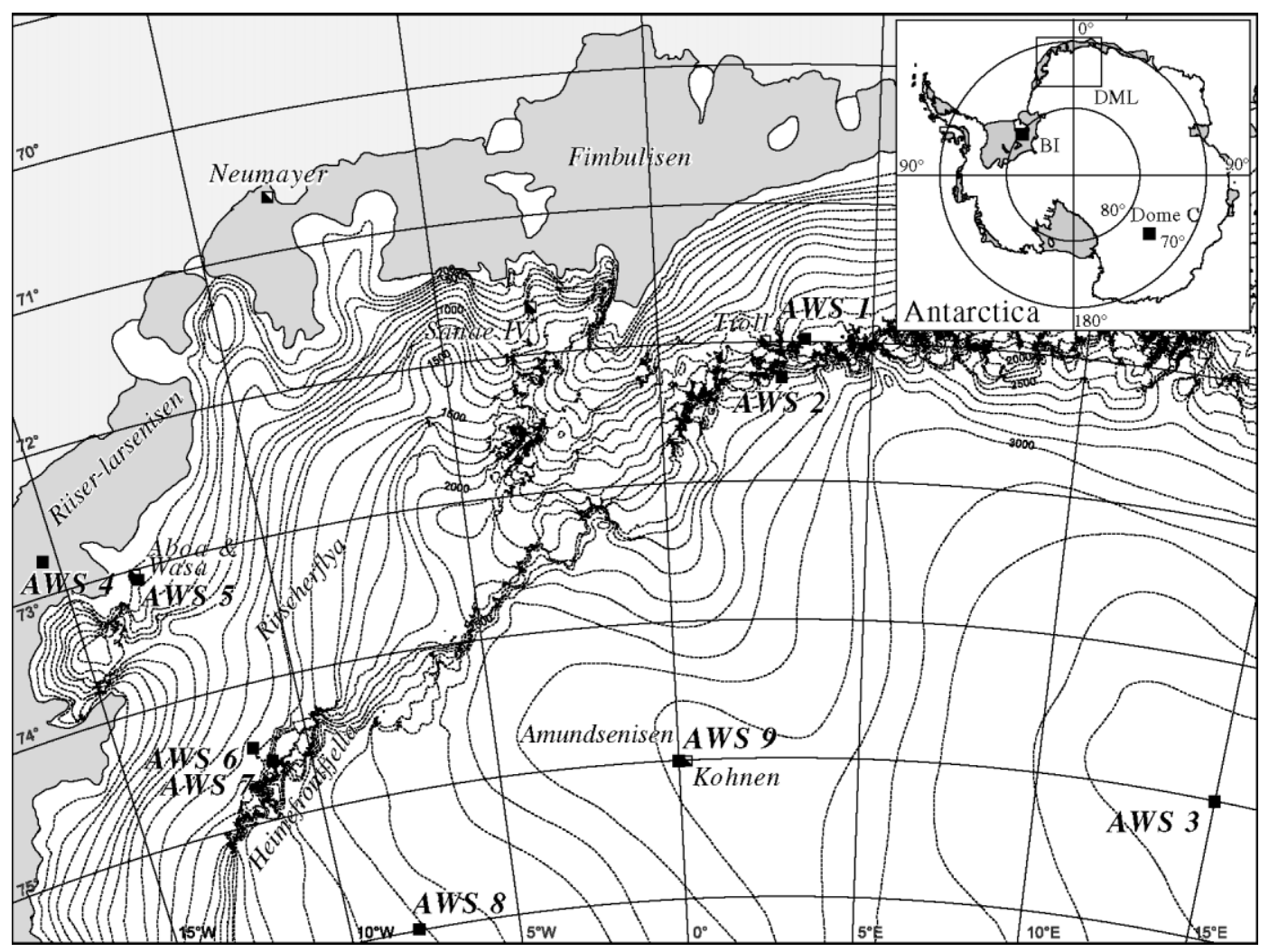

Fig. 1. Map of Dronning Maud Land (DML), Antarctica, showing the locations of the AWSs. AWS 9 is situated $2 \mathrm{~km}$ west of Kohnen station, the EPICA deep-drilling site. In the inset map of Antarctica the marked area is DML, and BIdenotes the Berkner Island AWS (map courtesy of the Norwegian Polar Institute, Tromsø, 2000).

Schlosser and Van Lipzig, 2002). Thermistors yield a continuous record, but the limited vertical resolution of the temperature sensors complicates the interpretation.

The measurements presented here comprise a 7 year dataset for the Berkner Island AWS (henceforth BI), and a 4 year dataset for the AWSs in DML. In section 2, the location of the sonic altimeters and the experimental set-up are described, and in section 3 the main mechanisms leading to snowfall on Antarctica. In sections 4-7, the measurements are described in terms of the measured time series, interannual variability, seasonal variability and event frequency, and in section 8 the results are summarized.

\section{LOCATION AND EXPERIMENTAL SET-UP}

The Institute for Marine and Atmospheric Research Utrecht (IMAU), The Netherlands, operates ten AWSs in Antarctica. One is located on the south dome of Berkner Island (Reijmer and others, 1999), and the other nine in DML

Table 1. AWS characteristics. Nearly all AWSs are located on snow; only AWS 7 is located on blue ice

\begin{tabular}{|c|c|c|c|c|c|}
\hline$A W S$ & Location & $\begin{array}{c}\text { Elevation } \\
\text { m a.s.l. }\end{array}$ & $\begin{array}{c}\text { Distance } \\
\mathrm{km}\end{array}$ & Operational dates & $\begin{array}{c}\rho \\
\mathrm{kg} \mathrm{m}^{-3}\end{array}$ \\
\hline 1 & $71^{\circ} 54.0^{\prime} \mathrm{S}, 3^{\circ} 05.0^{\prime} \mathrm{E}$ & 1420 & 220 & 31 Dec 1996 to 13 Dec 2000 & $370 \pm 23^{\mathrm{a}}$ \\
\hline 2 & $72^{\circ} 15.1^{\prime} \mathrm{S}, 2^{\circ} 53.5^{\prime} \mathrm{E}$ & 2400 & 250 & 3 Jan 1997 to 14 Dec 2000 & $325 \pm 25^{\mathrm{a}}$ \\
\hline 3 & $75^{\circ} 00.0^{\prime} \mathrm{S}, 15^{\circ} 00.1^{\prime} \mathrm{E}$ & 3453 & 590 & 28 Jan 1997 to $13 \operatorname{Jan} 2001$ & $325 \pm 20^{\mathrm{a}}$ \\
\hline 4 & $72^{\circ} 45.2^{\prime} \mathrm{S}, 15^{\circ} 29.9^{\prime} \mathrm{W}$ & 34 & 60 & 19 Dec 1997 to present & $390 \pm 50^{\mathrm{b}}$ \\
\hline 5 & $73^{\circ} 06.3^{\prime} \mathrm{S}, 13^{\circ} 09.9^{\prime} \mathrm{W}$ & 363 & 140 & 2 Feb 1998 to present & $450 \pm 26^{\mathrm{b}}$ \\
\hline 6 & $74^{\circ} 28.9^{\prime} \mathrm{S}, 11^{\circ} 31.0^{\prime} \mathrm{W}$ & 1160 & 290 & 14 Jan 1998 to present & $450 \pm 50$ \\
\hline 7 & $74^{\circ} 34.7^{\prime} \mathrm{S}, 11^{\circ} 03.0^{\prime} \mathrm{W}$ & 1172 & 300 & 31 Dec 1997 to present & - \\
\hline 8 & $76^{\circ} 00.0^{\prime} \mathrm{S}, 8^{\circ} 03.0^{\prime} \mathrm{W}$ & 2399 & 460 & 12 Jan 1998 to present & $345 \pm 22^{\mathrm{b}}$ \\
\hline 9 & $75^{\circ} 00.2^{\prime} \mathrm{S}, 0^{\circ} 00.4^{\prime} \mathrm{E}$ & 2892 & 540 & 29 Dec 1997 to present & $335 \pm 25^{c}$ \\
\hline BI & $79^{\circ} 34.0^{\prime} \mathrm{S}, 45^{\circ} 46.9^{\prime} \mathrm{W}$ & 886 & 175 & $12 \mathrm{Feb} 1995$ to present & $368.2 \pm 61^{\mathrm{d}}$ \\
\hline
\end{tabular}

Notes: BI, Berkner Island; Distance, the approximate distance of the site from the coast; $\rho$, mean firn density based on firn-core measurements averaged over the top $0.5 \mathrm{~m}$ of firn.

Sources: ${ }^{\mathrm{a}}$ van den Broeke, unpublished data, 1999. ${ }^{\mathrm{b}}$ Data courtesy of L. Karlöf, Norwegian Polar Institute, Tromsø, 1999. ' Data courtesy of H. Oerter, Alfred Wegener Institute, Bremerhaven, 2000. dOerter (1995). 
(Reijmer and Oerlemans, 2002) (Fig. 1; Table 1). Nearly all the stations are located on snow. Only AWS 7 is located on blue ice and therefore omitted from this study; results from this station are presented by Bintanja and Reijmer (2001). Note that AWS 9 is located at DML05, 2 km west of Kohnen station, the EPICA drilling site in DML. In the remainder of the paper the altimeter locations are denoted by the numbers of the AWSs they are mounted on.

The AWSs monitor the surface height using sonic altimeters. Changes in measured height are a measure for the surface mass balance. A sonic altimeter measures the height of the sensor above the surface by means of sound pulses. The time travelled by a sound pulse from the sensor to the surface and back, and the speed of sound in dry air at $0^{\circ} \mathrm{C}$ determine the measured height above the surface $H_{\mathrm{i}}$ (in m) of the instrument. Air temperature and moisture influence the speed of sound, and $H_{\mathrm{i}}$ is corrected for temperatures deviating from $0^{\circ} \mathrm{C}$ in the following way:

$$
H=H_{\mathrm{i}} \sqrt{\frac{T}{273.16}},
$$

with $T$ the air temperature in $\mathrm{K}$, and $H$ the corrected height in $\mathrm{m}$. Owing to the low moisture-holding capacity of the cold Antarctic air, the uncertainty introduced by moisture in the air is smaller than the uncertainty in the temperature measurements and therefore neglected. The sonic altimeters are Anderaa sensors at BI and AWSs 1-3, and Campbell SR50 sensors at AWSs 4-9. The Anderaa sensors have a range of $1-4 \mathrm{~m}$, and the Campbell sensors have a range of $0.5-10 \mathrm{~m}$. The accuracy of both sensor types is $\sim 0.01 \mathrm{~m}$ including the uncertainty introduced by the temperature correction. During the measuring period, there was no evidence of build-up of microstructures of snow around the weather-station mast. The uncertainty in the measurements is estimated to be $\sim 0.02 \mathrm{~m}$.

To calculate the mass balance from the surface height measurements, the measured height changes are multiplied by the snow density. The snow densities at the AWS locations are derived from firn-core and snow-pit measurements by weighing a known volume of snow or ice as a function of snow depth. The accuracy of this method is estimated to be $2-10 \%$ depending on the equipment used. Since the density is measured only once at the different locations, temporal variations in snow density are not taken into account, which introduces an additional uncertainty of $\sim 5 \%$. Mean densities over the top $0.50 \mathrm{~m}$ of the snow pit or firn core are taken into account for the settling and densification of the snowpack over time. The resulting densities and uncertainty estimates are presented in Table 1 . An additional factor affecting the estimated mass balance is the slow downward movement of the AWS. However, this effect is small compared to the uncertainty in the height measurements and density estimation.

In addition to the surface height, the AWSs measure air temperature, wind speed, wind direction, air pressure, incoming shortwave radiation and firn temperature (Fig. 2). AWSs 4-9 additionally measure relative humidity, reflected shortwave radiation and incoming and outgoing longwave radiation. Upon installation of the AWS, the initial height of the instruments is $\sim 3 \mathrm{~m}$ above the surface. The altimeters sample every 3 hours (BI and AWSs 1-3) or 2 hours (AWSs 4-9). The stations store the data locally and transmit them using Argos transmitters. The stations are powered with lithium batteries and are designed to work for 2-3 years

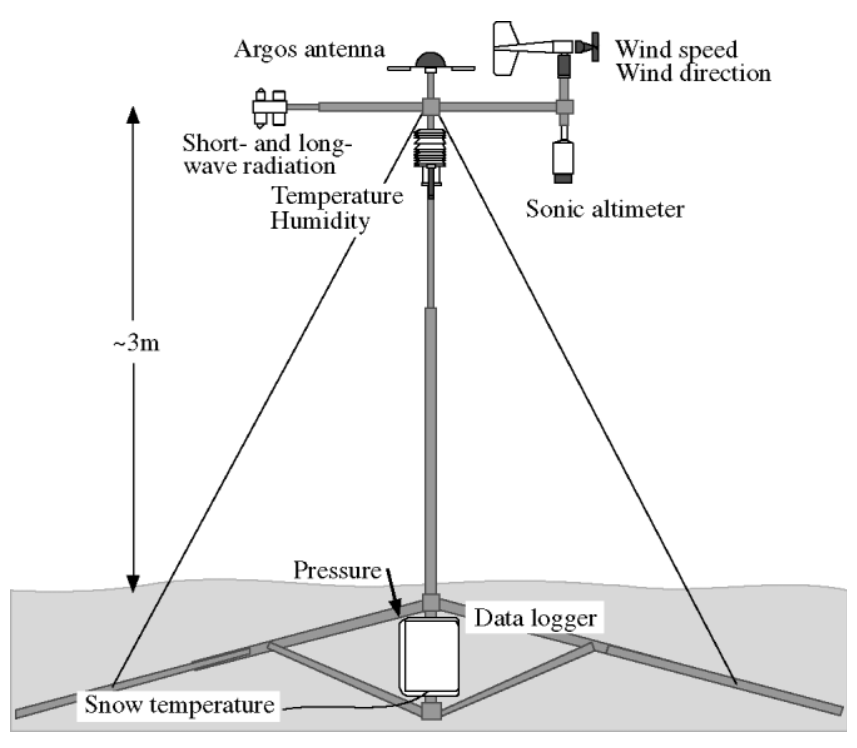

Fig. 2. Schematic picture of an AWS.

without being serviced. A problem experienced with the AWS is occasional rime formation on the sensors, which shields the sonic altimeters. Problems with data transmission occasionally result in gaps in the dataset. AWSs 3, 8 and 9 stop transmitting in winter due to low temperatures $\left(<-55^{\circ} \mathrm{C}\right.$ in the logger box $)$. Low temperatures make the height measurements at AWS 3 unreliable in winter and only annual mass-balance values are presented for this site.

\section{PREVAILING SYNOPTIC GONDITIONS}

All precipitation in Antarctica, except for some parts of the northern Antarctic Peninsula region, falls as snow. The main mechanisms leading to snowfall in the coastal regions of Antarctica and on the East Antarctic plateau are described by, for example, Bromwich (1988), King and Turner (1997) and Cullather and others (1998). They show that snowfall in the coastal areas of Antarctica is often orographically induced. The high Antarctic ice sheet forces the air to rise, resulting in enhanced snowfall in the escarpment regions of the plateau. The elevated terrain prevents the penetration of synoptic disturbances onto the interior plateau. The depressions associated with the snowfall in the coastal regions therefore seldom penetrate far inland, and

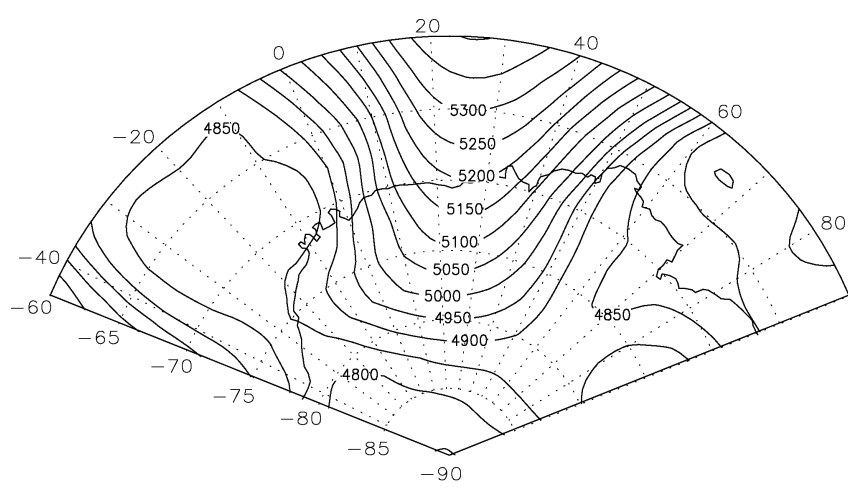

Fig. 3. Height of the 500 hPa level ( $m$ ) for 13 May 1998, $1200 \mathrm{~h}$, based on the European Centre for Medium-Range Weather Forecasts operational analysis data. 


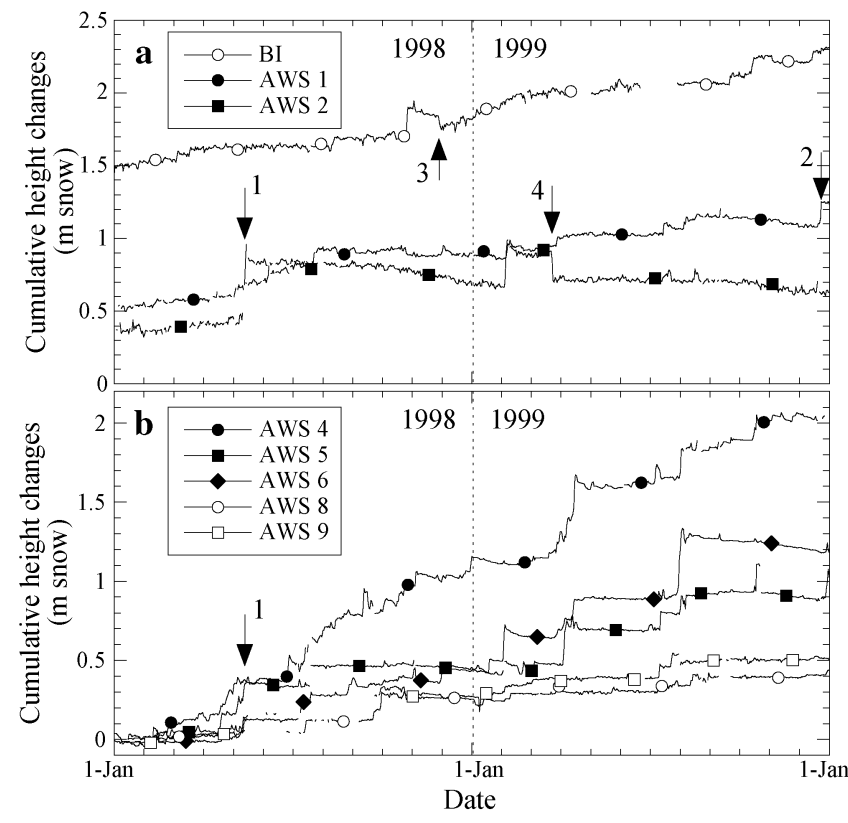

Fig. 4. Cumulative daily values of surface height changes ( $m$ snow) for 1998-99 at (a) Berkner Island (BI) and AWSs 1 and 2, and (b) AWSs 4-9. The surface height change is $0 \mathrm{~m}$ snow at the beginning of the record of each station ( Table 1).

snowfall over the higher parts of the Antarctic plateau may also be associated with radiative cooling of the air instead of orographic lifting ("clear-sky precipitation" or "diamond dust"). The snowfall amounts on the plateau are usually small.

Most of the snowfall in western DML is associated with the development of an amplified wave pattern in the upper troposphere, with a low-pressure area over the Weddell Sea area and a high-pressure ridge over eastern DML (Fig. 3) (Noone and others, 1999). This amplified wave pattern enhances northerly advection over the shelf area, and, in combination with the steep orography of DML, the air is forced to rise and snowfall is enhanced. The development of this type of flow pattern occurs only a few times per year and is also responsible for snowfall in other regions of Antarctica (Bromwich, 1988). On Berkner Island, snowfall occurs when a depression moves far south through the Weddell Sea. In the eastern sector of these depressions warm moist air is advected southward, occasionally bringing snow to Berkner Island. In both DML and Berkner Island the meteorological conditions associated with snowfall are exceptional with respect to the average conditions (Noone and others, 1999; Reijmer and van den Broeke, 2001).

\section{TIME SERIES OF SURFAGE HEIGHT MEASUREMENTS}

The measured surface-height changes include processes such as snowfall, snowdrift, sublimation, deposition and densification of the snowpack. It is difficult to assess how much and when a surface height increase is snowfall or snowdrift, since accumulation is generally accompanied by strong winds (Reijmer and van den Broeke, 2001). Some of these processes are, however, detectable in the measured time series.

Figure 4 presents time series of cumulative daily surface

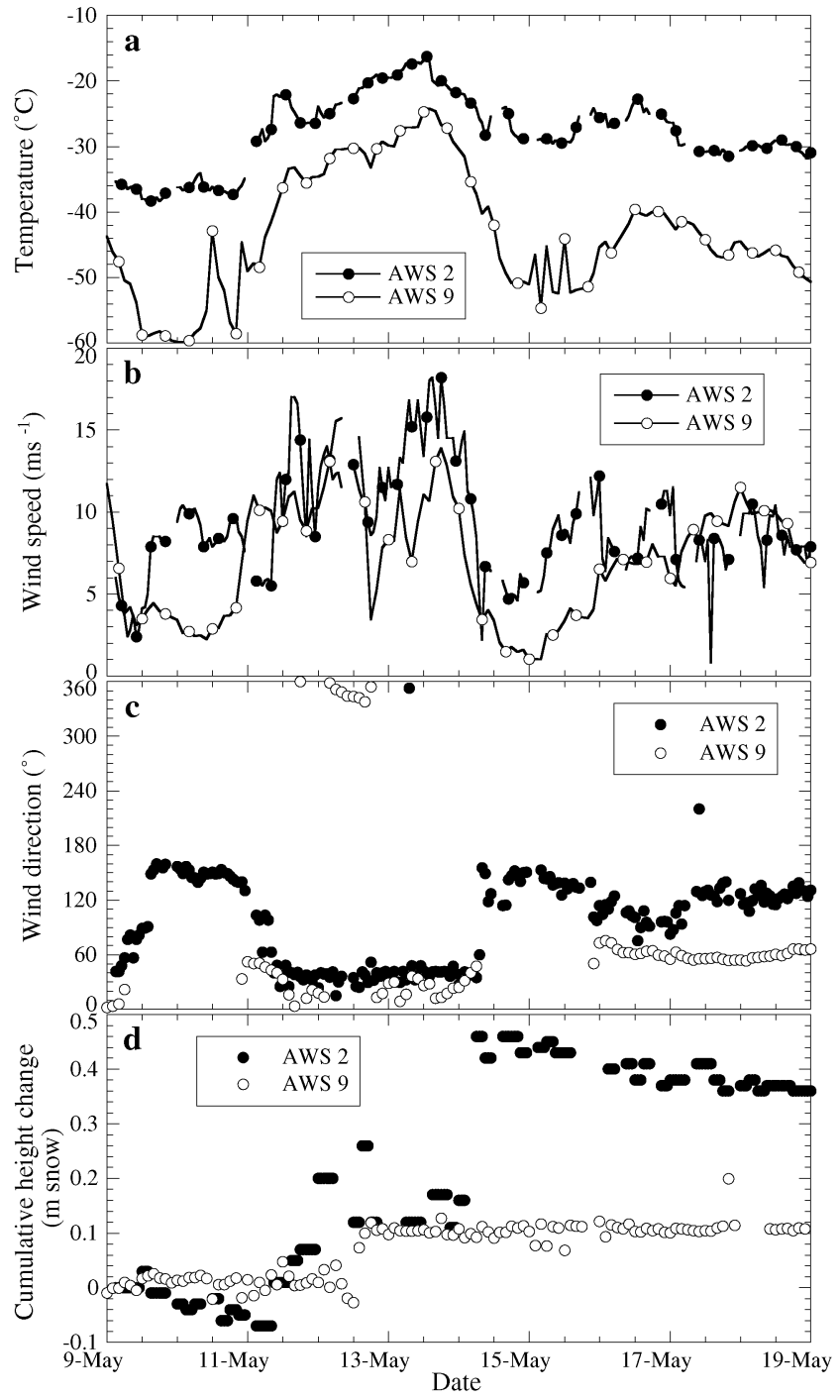

Fig. 5. Hourly ( AWS 2) and 2 hourly mean variation of temperature ( $a$ ), wind speed ( $b$ ), wind direction ( $c$ ) and cumulative surface height change (d) for a snowfall event in May 1998 ( Fig. 4, arrow 1). The surface height change is $0 \mathrm{~m}$ snow at 9 May.

height changes for 1998 and 1999. Gaps in the records result from rime formation on the sensors or problems with the data transmission. The height change at all sites is positive, i.e. accumulation outweighs ablation. At the lower sites (AWSs 4-6) temperatures in summer occasionally rise above $0^{\circ} \mathrm{C}$ for a few hours and melt may occur (Reijmer and Oerlemans, 2002). The meltwater refreezes locally in the cold snowpack and slightly influences the height measurements and, therewith, the computed mass balance through enhanced densification of the snowpack.

The records show high temporal and spatial variability in the measured height changes. Accumulation occurs in numerous small events of 1 or $2 \mathrm{~cm}$ and a few larger events of $\geq 5 \mathrm{~cm}$ of snow. In DML the large accumulation events are associated with the development of an amplified wave pattern in the upper troposphere (Fig. 3) which occurs only a few times per year. The major events occur four to five times per year, with no clear seasonality, and often bring snow over large areas. In the AWS data, these events coincide with relatively high temperatures, specific humidities and wind speeds, and a turning of the wind from predominant easterly (katabatic) directions to more northerly directions. Figure 5 shows an example of these conditions for an 
Table 2. Annual surface mass balance ( $m$ m w.e. $a^{-1}$ ) based on sonic altimeter and density measurements ( Table 1). The given uncertainty is based on the uncertainty in the determined surface height change and snow density

\begin{tabular}{|c|c|c|c|c|c|c|c|c|c|}
\hline \multirow[b]{2}{*}{$A W S$} & \multicolumn{9}{|c|}{ Annual surface mass balance } \\
\hline & 1995 & 1996 & 1997 & 1998 & 1999 & 2000 & 2001 & Mean & Std dev. \\
\hline 2 & - & - & $111 \pm 27$ & $88 \pm 15$ & $13 \pm 13$ & $114 \pm 21$ & - & $81 \pm 28$ & 47 \\
\hline 3 & - & - & $3 \pm 16$ & $62 \pm 14$ & $39 \pm 16$ & $29 \pm 13$ & - & $33 \pm 25$ & 24 \\
\hline 4 & - & - & - & $437 \pm 58$ & $371 \pm 49$ & $316 \pm 43$ & $378 \pm 62$ & $375 \pm 59$ & 49 \\
\hline 5 & - & - & - & $144 \pm 28$ & $270 \pm 27$ & $153 \pm 13$ & $140 \pm 24$ & $177 \pm 36$ & 63 \\
\hline 6 & - & - & - & $207 \pm 25$ & $333 \pm 38$ & $320 \pm 38$ & $252 \pm 28$ & $278 \pm 39$ & 59 \\
\hline 8 & - & - & - & $90 \pm 9$ & $62 \pm 5$ & $28 \pm 4$ & $104 \pm 7$ & $71 \pm 15$ & 34 \\
\hline 9 & - & - & - & $90 \pm 8$ & $84 \pm 7$ & $60 \pm 6$ & $90 \pm 10$ & $81 \pm 15$ & 14 \\
\hline BI & $250 \pm 45$ & $144 \pm 26$ & $107 \pm 19$ & $155 \pm 27$ & $177 \pm 30$ & $162 \pm 33$ & $0 \pm 5$ & $142 \pm 28$ & 76 \\
\hline
\end{tabular}

Notes: BI, Berker Island; Std dev., standard deviation in the annual means.

event in May 1998 (Fig. 4, arrow 1). This event appears in the records of AWSs 1, 2, 5, 6 and 9.

Other events are more local. For example, about $15 \mathrm{~cm}$ of snow accumulated at AWS 1 in December 1999 (Fig. 4, arrow 2) whereas no accumulation occurred at any of the other sites. These events are also associated with high wind speeds and the wind turning in more northerly directions. However, advection of warm moist air is less. Over the Antarctic continent, precipitation is partly caused by radiative cooling (clear-sky precipitation). This type of precipitation was not detected at the sites on the Antarctic plateau (AWSs 8 and 9). The amount of accumulation associated with this type of precipitation is very small and therefore difficult to detect using the sonic altimeters. Since both sites are located reasonably close to the escarpment region $(\sim 200 \mathrm{~km})$ and coast $(\sim 500 \mathrm{~km})$ compared to the characteristic length scale of a cyclonic system $(\sim 1000 \mathrm{~km})$, most of the accumulation at these sites is also associated with the development of an amplified wave pattern in the upper troposphere.

Decreases in surface height are caused by wind erosion, densification and sublimation. Stepwise decreases in sensorheight changes are almost certainly caused by wind erosion, since the other two processes bring about more gradual changes. Clear examples of wind erosion are the mass losses in November 1998 at BI and March 1999 at AWS 2 (Fig. 4, arrows 3 and 4). Wind speeds exceeding 10 and $15 \mathrm{~m} \mathrm{~s}^{-1}$ prevailed at BI and AWS 2, respectively, at that time. More gradual decreases in sensor-height changes are caused by densification and sublimation of the snowpack. Both processes have the largest impact in summer. The increased densification through the occasional occurrence of melt at AWSs 4-6 is probably small, and the resulting increase in sensor height is not detectable in the time series. The amount of sublimation is also generally small and varies between 0 and $20 \mathrm{~mm}$ w.e. $\mathrm{a}^{-1}$ (Reijmer and Oerlemans, 2002). Most sublimation occurs in summer. Locally, not all accumulation events result in annual accumulation. In February 1999 about $30 \mathrm{~cm}$ of snow accumulated at AWS 2 in one event, but almost everything was blown away at the end of March 1999, resulting in an almost zero annual surface mass balance in 1999 (Fig. 4, arrow 4).

\section{THE ANNUAL SURFAGE MASS BALANGE}

Annual surface mass-balance values are presented inTable 2 in $\mathrm{mm}$ w.e. $\mathrm{a}^{-1}$, which is the surface height change in $\mathrm{m}$ snow multiplied by the snow density (Table 1). The given uncertainties are based on the uncertainty in the determined surface height changes and snow densities.

As can be seen in the time series and Table 2, annual accumulation occurs at all sites, and the amount of accumulation generally decreases with increasing distance from the coast. The annual accumulation is highest at AWS 4 , at $\sim 60 \mathrm{~km}$ from the coast with an average value of $375 \pm 59 \mathrm{~mm}$ w.e. $\mathrm{a}^{-1}$ and decreases to values $<100 \mathrm{~mm}$ w.e. $\mathrm{a}^{-1}$ on the Antarctic plateau. At AWS 6, $\sim 278 \pm 39$ mm w.e. $\mathrm{a}^{-1}$ accumulates, which is high compared to AWSs 1, 2 and 5, which are all sites located closer to the coast. This can be explained by the spatial variations in the coastal-inland surface mass-balance gradient (Vaughan and others, 1999) as well as the local topography, resulting in large variations in snowfall, and wind erosion and deposition of snow in mountainous areas (Melvold and others, 1998; van den Broeke and others, 1999). The difference in amount of annual accumulation between AWSs 1 and 2 is considerable (on average $\sim 46 \mathrm{~mm}$ w.e. $\mathrm{a}^{-1}$ ) given that the sites are located only $30 \mathrm{~km}$ apart. Melvold and others (1998) also found large accumulation differences over small distances in this area, which they attributed to elevational differences and differences in orientation and size of the surface slope. Richardson and Holmlund (1999) also found a decrease in annual mass balance with increasing elevation in this area of DML and attributed it partly to the stronger influence of coastal cyclonic systems in the lower parts of the escarpment region.

On the Antarctic plateau the measured annual accumulation varies between 90 and $30 \mathrm{~mm}$ w.e. $\mathrm{a}^{-1}$, which is comparable to the values presented by Oerter and others (2000) for the plateau area surrounding DML05. The amount of annual accumulation at AWS 9 is slightly higher than at AWS 8 over this 4 year period, but the difference is not significant due to the large interannual variability. The lowest amount of annual accumulation is observed at AWS 3 (on average $\sim 33 \pm 25 \mathrm{~mm}$ w.e. $\mathrm{a}^{-1}$ ), the site farthest from the coast $(\sim 590 \mathrm{~km})$ and with the highest surface elevation (3453 m a.s.l.).

The year-to-year variability is considerable at all locations. Standard deviations in the 4-7 year annual averages range from $20 \%$ to $70 \%$ of the average annual accumulation. The standard deviations in the averages are largest $(>50 \%)$ at AWSs $1-3$ and BI owing to exceptionally low annual accumulation rates in 1997 (AWS 3), 1999 (AWS 2), 2000 (AWS l) and 2001 (BI), and the short time series of 7 
Table 3. Surface mass-balance averages derived from snow pits and shallow firn cores

\begin{tabular}{|c|c|c|c|}
\hline Site & $\begin{array}{l}\text { Dist. } \\
\mathrm{km}\end{array}$ & Period & $\begin{array}{l}M B \\
\text { mm w.e. } \mathrm{a}^{-1}\end{array}$ \\
\hline $\begin{array}{l}\text { (AWS 1) site } \mathrm{A}^{\mathrm{a}} \\
\left(\text { AWS 2) site } \mathrm{C}^{\mathrm{a}}\right. \\
\text { (AWS 3) site } \mathrm{M}^{\mathrm{a}} \\
\text { (AWS 4) site } \mathrm{C}^{\mathrm{b}} \\
\text { (AWS 5) site } \mathrm{D}^{\mathrm{b}} \\
\text { (AWS 6) site } \mathrm{H}^{\mathrm{b}} \\
\text { (AWS 8) } \mathrm{CV}^{\mathrm{c}} \\
\text { (AWS 9) DML05 } \\
\text { (BD) South Dome }\end{array}$ & $\begin{array}{l}0 \\
0 \\
0 \\
31 \\
39 \\
15 \\
0 \\
0 \\
10\end{array}$ & $\begin{array}{l}1965-97 \\
1965-97 \\
1965-97 \\
1976-89 \\
1974-89 \\
1973-89 \\
1965-97 \\
1801-97 \\
1969-89\end{array}$ & $\begin{array}{l}135 \pm 10 \\
123 \pm 9 \\
45 \pm 4 \\
415 \\
343 \\
318 \\
68 \\
62 \pm 21 \\
174+38\end{array}$ \\
\hline
\end{tabular}

Notes: Dist., approximate distance between the location of the snow pit or firn core and the closest AWS; MB, surface mass balance from the literature. The AWS closest to the location of the firn core or snow pit is shown in parentheses.

Sources: ${ }^{\mathrm{a}}$ van den Broeke and others (1999). ${ }^{\mathrm{b}}$ Isaksson and Karlén (1994). ${ }^{\mathrm{c}}$ Karlöf and others (2000). ${ }^{\mathrm{d}}$ Oerter and others (2000). ${ }^{\mathrm{e}}$ Wagenbach and

and 4 years. The interannual variability is partly explained by the large variability in the development of the amplified wave pattern in the upper troposphere in terms of number of developments per year and the stability of the pattern. The longer the pattern exists, the more heat and moisture is transported towards the continent. The differences in interannual variability between the sites are partly related to differences in location of the wave patterns and the considerable distance $(\sim 100$ to $\sim 1000 \mathrm{~km})$ between the sites.

The sonic-altimeter-derived annual mass balances are in good agreement with firn cores and snow pits, with the exception of AWS 5 (Table 3). The discrepancy at AWS 5 is explained by the considerable distance $(\sim 40 \mathrm{~km})$ between AWS 5 and site D of Isaksson and Karlén (1994). The averaged annual accumulation over the last 4-7 years at the AWS sites is lower than the firn-core averages over the last 20-200 years, except for AWSs 8 and 9. Differences can be explained by spatial variability in annual accumulation and differences in measuring period.

\section{SEASONAL VARIABILITY}

In the following analyses seasons are defined as follows: summer: December-February; autumn: March-May; winter: June-August; spring: September-November. The seasonality of the accumulation is important for ice-corederived annual averaged temperature records. The records will be biased towards the season or month in which most of the accumulation occurs, resulting in an overestimate of the year-to-year variability when seasonality varies (Van Lipzig and others, 2002a). Figure 6 presents the seasonal cycle in the accumulation for BI, and AWSs 4, 6 and 9.

BI shows on average a minimum in autumn and winter, with a total of $\sim 30 \%$ of the annual average accumulation occurring in these two seasons. This corresponds well with earlier measurements at Ellsworth, a station near the edge of the Filchner Ice Shelf (Bromwich, 1988). The seasonal cycles are mainly determined by the larger accumulation events, and as a result considerable interannual variations occur. The average seasonal cycle at BI is barely significant at the $5 \%$ level. At AWSs 1, 4, 5 and 6 the accumulation is

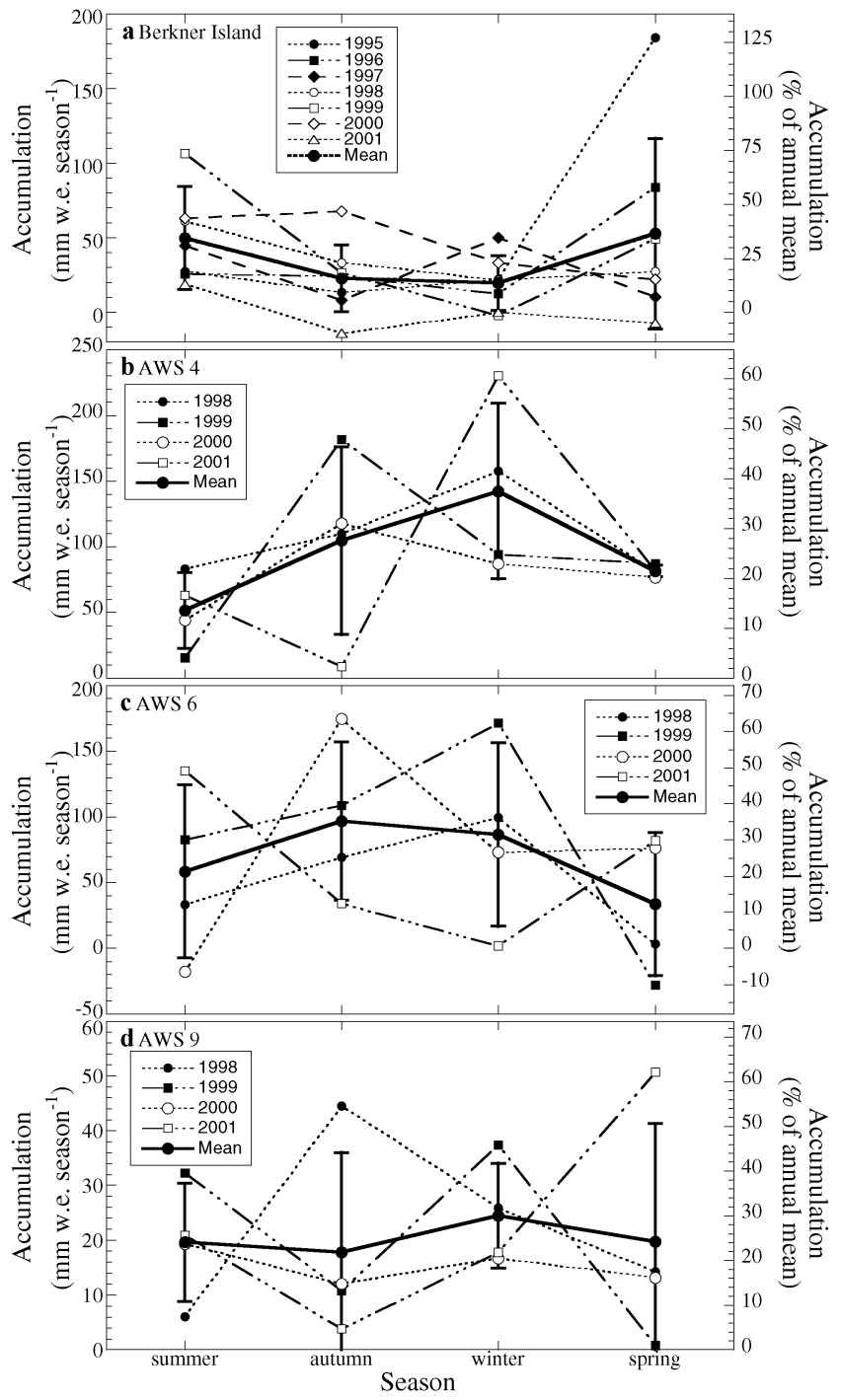

Fig. 6. Seasonal variations in the surface mass balance (per year and averaged) at Berkner Island (BI) (a), AWS 4 (b), AWS 6 (c) and AWS 9 (d) in mm w.e.per season (left scales) and as percentage of the averaged annual mass balance (right scales). The error bars denote the standard deviation in the averages. Seasons are defined as: summer: December-February; autumn: March-May; winter: June-August; spring: September-November.

highest in autumn and winter, with $65-75 \%$ of the annual accumulation occurring in these seasons. At AWSs 1, 4 and 5 the autumn or winter maximum differs significantly from the spring or summer minimum. At AWS 6 the difference between maximum and minimum is not significant, mainly due to the reversed cycle in 2001 when accumulation was lowest in autumn and winter. At Neumayer and other coastal stations of East Antarctica, the maximum accumulation also occurs in winter (Bromwich, 1988; Schlosser and Van Lipzig, 2002). This maximum in the winter months can be explained by the larger depression intensity and activity in these months. The time series are too short and the variability too large to permit comment on variations on a monthly time-scale.

At the higher sites, AWSs 2, 8 and 9, the accumulation is roughly constant throughout the year, with a small tendency towards lower values in winter at AWSs 2 and 8 . The interannual variability is considerable. For example, in 1998 accumulation was highest in autumn and winter, while in 


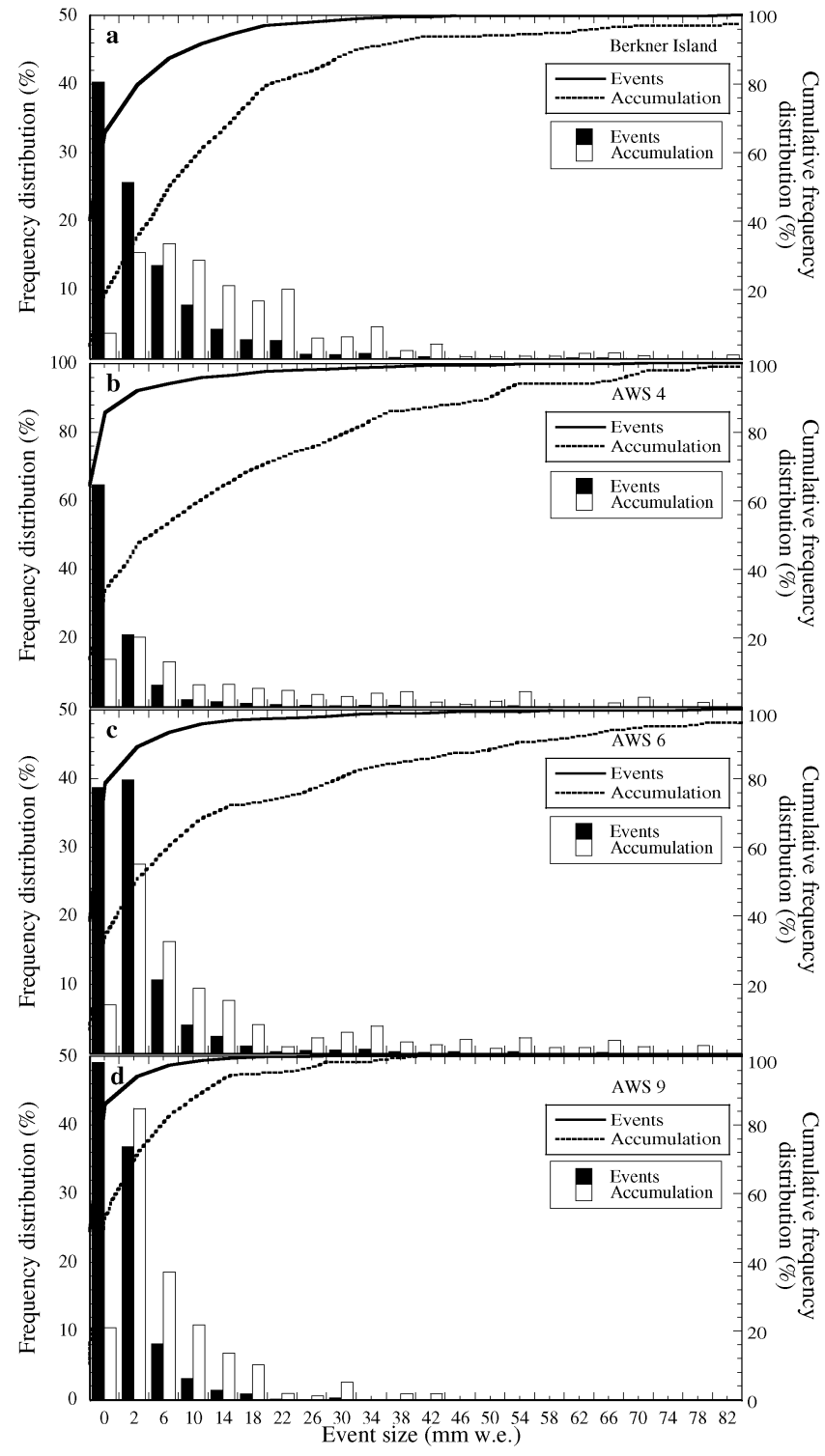

Fig. 7. Frequency distribution (left scale, histogram) and cumulative frequency distribution (right scale, lines) in percentage of the number of events (solid bars and lines) and amount of accumulation (open bars and dotted lines) at Berkner Island (BI) (a), AWS 4 (b), AWS 6 (c) and AWS 9 (d) as a function of event size in mm w.e. The bin size is $4.0 \mathrm{~mm}$ w.e., and all events $>0.0 \mathrm{~m}$ snow are taken into account.

2001 accumulation was lowest in these seasons. The higher values in the summer are explained by the higher temperatures and larger moisture content of the atmosphere in the summer months. However, at South Pole and Vostok a maximum in accumulation is observed in winter (Bromwich, 1988). Note that the annual variability in the measurements is considerable and results in seasonal averages that are not significantly different at four of the eight sites.

\section{STATISTICAL DISTRIBUTION}

In addition to seasonality, the size of individual precipitation events, the timing of the events and the meteorological conditions during the events will also influence the record retrieved from ice cores. In this section, we discuss the nature of the accumulation. In the following analyses an accumulation event is defined when the surface height change in a 12 hour period (0000-1200 and 0012-0024 h) is non-zero. In practice, events of $<2 \mathrm{~cm}$ snow, which is the accuracy of the surface height measurements, are taken into account, even though these may not be true events.

Figure 4 suggests that most accumulation in DML occurs in four to five events per year. The frequency distribution and cumulative frequency distribution of number of events and amount of accumulation over different event size bins is presented in Figure 7 for BI and AWSs 4,6 and 9. The number of events and the amount of accumulation per bin decreases with increasing event size at all sites. The decrease in number of events is larger than the decrease in amount of accumulation, illustrating the tendency of the accumulation to occur in larger events.

The tendency of larger events to contribute more to the total amount of accumulation is a function of distance from the coast, elevation and annual accumulation. Near the coast (AWSs 4 and 5) the bias towards larger events is greatest. In the coastal area, $50 \%$ of the accumulation is deposited in $\sim 7 \%$ of the events and $10 \%$ in only $\sim 1 \%$ of the events. On the plateau, more accumulation is deposited in smaller events, and $50 \%$ of the accumulation is deposited in $\sim 15 \%$ of the events. The escarpment region is more variable. The distribution at AWS 6 is very similar to that at AWSs 8 and 9, while at AWSs 1 and 2 the tendency towards small events is largest, with $50 \%$ of the accumulation deposited in $\sim 22 \%$ of the events. This is likely due to the specific orographic location of these sites. The conditions on BI are comparable to those at AWSs 6, 8 and 9.

The amount of accumulation contributed by small events increases with increasing distance from the coast, towards higher elevations and lower accumulation amounts. In terms of event size, $75 \%$ of the accumulation on the plateau (AWSs 8 and 9) is deposited in events of $<10 \mathrm{~mm}$ w.e. and $25 \%$ in events $\geq 10 \mathrm{~mm}$ w.e. Most of the accumulation on the plateau is caused by small events; $90 \%$ of all accumulation occurs in events of $<20$ mm w.e. $(\sim 0.06 \mathrm{~m}$ snow $)$ while in the coastal area the $90 \%$ level lies at $\sim 55 \mathrm{~mm}$ w.e. ( $\sim 0.14 \mathrm{~m}$ snow, AWS 4$)$. No events of $>55 \mathrm{~mm}$ w.e. $(\sim 0.16 \mathrm{~m}$ snow) occur on the plateau whereas the largest events, of $>90 \mathrm{~mm}$ w.e., occur in the escarpment region and on Berkner Island. In the escarpment region (AWSs 1, 2 and 6) the variability in event size is large owing to large variations in snowdrift erosion and deposition near mountainous areas (Melvold and others, 1998; van den Broeke and others, 1999).

\section{SUMMARY AND CONGLUDING REMARKS}

This paper presents surface height measurements carried out with sonic altimeters mounted on AWSs in DML and on Berkner Island. The measured surface-height changes are multiplied by measured snow densities to obtain an estimate of the surface mass balance. The mass balances determined include processes such as snowfall, snowdrift divergence, sublimation, deposition and densification of the snowpack. From the data presented it is difficult to distinguish between snowfall and snowdrift or sublimation and densification, and no attempt is made to do so.

The records show that the surface mass balance at all sites is positive, i.e. accumulation outweighs ablation. The records also show large temporal and spatial variability. Accumulation occurs in numerous small events of 1 or $2 \mathrm{~cm}$ of snow and a few larger events of $\geq 5 \mathrm{~cm}$ of snow. The small 
events are more local; the larger events may cover larger areas of a few hundred square kilometres. Other processes detectable in the records are erosion by snowdrift and densification/sublimation of the snowpack. Snowfall in the form of clear-sky precipitation was not detected.

The accumulation generally decreases with increasing distance from the coast and increasing elevation. Annual averaged values range from $\sim 375 \pm 59$ mm w.e. $\mathrm{a}^{-1}$ near the coast to $\sim 33 \pm 25 \mathrm{~mm}$ w.e. $\mathrm{a}^{-1}$ on the Antarctic plateau. These values are in good agreement with long-term averaged annual accumulation rates obtained from snow pits and firn cores. The interannual variability is large, 20-70\% of the average annual accumulation, especially in the escarpment region where the wind speed is largest and can cause considerable erosion and deposition of snow. In some years the annual mass balance may even be zero or negative. This may result in the absence of an annual accumulation layer in an ice core or snow pit.

The records show seasonal dependency of the accumulation at BI that is barely significant at the $5 \%$ level. At AWSs 1, 4 and 5, seasonal dependency is significant, with a maximum in autumn or winter and a minimum in summer or spring. At AWS 6, there is a maximum in autumn and a minimum in spring, which is not significant, owing to the large interannual variability. At the higher sites (AWSs 2, 8 and 9) the accumulation is evenly distributed over the year, with a slight tendency towards a maximum in summer. The interannual variability is large at all sites, resulting in a possible bias in the annual averaged temperatures determined from ice cores towards the season or month with the most accumulation in that particular year, as shown by Van Lipzig and others (2002a).

A further complication in the analysis of temperature records from ice cores is the tendency of the accumulation to occur in several major snowfall events. The atmospheric conditions during these events are not representative of average conditions (Noone and others, 1999; Reijmer and Oerlemans, 2002). The number of events and the amount of accumulation per event decreases with increasing elevation and distance from the coast. Close to the coast, $50 \%$ of the accumulation is deposited in $\sim 7 \%$ of all events, while $10 \%$ is deposited in only $1 \%$ of all events. Further inland, in the escarpment region and on the plateau, $50 \%$ is deposited in $12-25 \%$ of all events.

\section{AGKNOWLEDGEMENTS}

We would like to thank P. Calanca and an anonymous reviewer for their useful comments. We would also like to thank the members of the SWEDARP 1997/98 expedition; the members of the German expeditions from the Alfred Wegener Institute, Bremerhaven, to Dronning Maud Land, especially H. Oerter; the members of the Norwegian traverse team of 1996/97 and 2000/01; and the members of the British Antarctic Survey expeditions to Berkner Island, especially R. Mulvaney, for their invaluable help with placing and servicing the AWSs. This work is a contribution to the "European Project for Ice Coring in Antarctica" (EPICA), a joint European Science Foundation/European Commission scientific programme, funded by the European Commission and by national contributions from Belgium, Denmark, France, Germany, Italy, the Netherlands, Norway, Sweden, Switzerland and the United Kingdom.
We thank R. Greve for his handling of the paper as Scientific Editor.

\section{REFERENGES}

Bintanja, R. and C. H. Reijmer. 2001. Meteorological conditions over Antarctic blue-ice areas and their influence on the local surface mass balance. F. Glaciol., 47(156), 37-50.

Bromwich, D. H. 1988. Snowfall in high southern latitudes. Rev. Geophys., 26(1), 149-168.

Cullather, R. I., D. H. Bromwich and M. L. Van Woert. 1998. Spatial and temporal variability of Antarctic precipitation from atmospheric methods. 7. Climate, 11 (3), 334-367.

Greenland Ice-Core Project (GRIP) Members. 1993. Climate instability during the last interglacial period recorded in the GRIP ice core. Nature, 364(6434), 203-207.

Isaksson, E. and W. Karlén. 1994. Spatial and temporal patterns in snow accumulation, western Dronning Maud Land, Antarctica. 7. Glaciol., 40 (135), 399-409.

Isaksson, E., M. R. van den Broeke, J.-G. Winther, L. Karlöf, J. F. Pinglot and N. Gundestrup. 1999. Accumulation and proxy-temperature variability in Dronning Maud Land, Antarctica, determined from shallow firn cores. Ann. Glaciol., 29, 17-22.

Jonsson, S. 1992. Local climate and mass balance of a blue-ice area in western Dronning Maud Land, Antarctica. Z. Gletscherkd. Glazialgeol., 26(1), [1990], 11-29.

Jouzel, J. and 12 others. 1997. Validity of the temperature reconstruction from water isotopes in ice cores. 7. Geophys. Res., 102(C12), 26,471-26,487.

Karlöf, L. and 13 others. 2000. A 1500 year record of accumulation at Amundsenisen, western Dronning Maud Land, Antarctica, derived from electrical and radioactive measurements on a $120 \mathrm{~m}$ ice core. f. Geophys. Res., $\mathbf{1 0 5}$ (D10), 12,471-12,483.

King, J. C. and J. Turner. 1997. Antarctic meteorology and climatology. Cambridge, Cambridge University Press.

Melvold, K., J. O. Hagen, J. F. Pinglot and N. Gundestrup. 1998. Large spatial variation in accumulation rate in Jutulstraumen ice stream, Dronning Maud Land, Antarctica. Ann. Glaciol., 27, 231-238.

Noone, D., J. Turner and R. Mulvaney. 1999. Atmospheric signals and characteristics of accumulation in Dronning Maud Land, Antarctica. F. Geophys. Res., 104(D16), 19,191-19,211.

Oerter, H. 1995. The German Filchner V campaign in 1995: an overview and preliminary results from Berkner Island. In Oerter, H., ed. FilchnerRonne Ice Shelf Programme (FRISP). Report No. 9 (1995). Bremerhaven, Alfred Wegener Institute for Polar and Marine Research, 91-96.

Oerter, H. and 6 others. 2000. Accumulation rates in Dronning Maud Land, Antarctica, as revealed by dielectric-profiling measurements of shallow firn cores. Ann. Glaciol., 30, 27-34.

Petit, J.-R. and 17 others. 1999. Climate and atmospheric history of the past 420,000 years from the Vostok ice core, Antarctica. Nature, 399(6735), 429-436.

Reijmer, C. H. and J. Oerlemans. 2002. Temporal and spatial variability of the surface energy balance in Dronning Maud Land, East Antarctica. 7. Geophys. Res., 107(D24), 4759-4770 [ACL9-1 to ACL9-12]. (10.1029/ 2000JD000110.)

Reijmer, C. H. and M. R. van den Broeke. 2001. Moisture sources of precipitation in western Dronning Maud Land, Antarctica. Antarct. Sci., $13(2), 210-220$.

Reijmer, G., W. Greuell and J. Oerlemans. 1999. The annual cycle of meteorological variables and the surface energy balance on Berkner Island, Antarctica. Ann. Glaciol., 29, 49-54.

Richardson, C. and P. Holmlund. 1999. Spatial variability at shallow snowlayer depths in central Dronning Maud Land, East Antarctica. Ann. Glaciol., 29, 10-16.

Schlosser, E., N. van Lipzig and H. Oerter. 2002. Temporal variability of accumulation at Neumayer station, Antarctica, from stake array measurements and a regional atmospheric model. f. Glaciol., 48(160), 87-94.

Steinhage, D., U. Nixdorf, U. Meyer and H. Miller. 1999. New maps of the ice thickness and subglacial topography in Dronning Maud Land, Antarctica, determined by means of airborne radio-echo sounding. Ann. Glaciol., 29, 267-272.

van den Broeke, M. R. and 6 others. 1999. Climate variables along a traverse line in Dronning Maud Land, East Antarctica. F. Glaciol., 45(150), 295302.

van den Broeke, M. R., N. P. M. van Lipzig and E. van Meijgaard. 2002. Momentum budget of the East-Antarctic atmospheric boundary layer: results of a regional climate model. 7. Atmos. Sci., 59(21), 3117-3129. 
Van Lipzig, N. P. M., E. van Meijgaard and J. Oerlemans. 2002a. The effect of temporal variations in the surface mass balance and temperature-inversion strength on the interpretation of ice-core signals. F. Glaciol.., 48(163), 611-621.

Van Lipzig, N. P. M., E. van Meijgaard and J. Oerlemans. 2002b. The spatial and temporal variability of the surface mass balance in Antarctica: results from a regional climate model. Int. f. Climatol., 22, 1197-1217.

Vaughan, D. G., J. L. Bamber, M. B. Giovinetto, J. Russell and A. P. R. Cooper. 1999. Reassessment of net surface mass balance in Antarctica. 7. Climate, 12(4), 933-946.
Wagenbach, D. and 6 others. 1994. Reconnaissance of chemical and isotopic firn properties on top of Berkner Island, Antarctica. Ann. Glaciol., 20, 307-312.

Werner, M., U. Mikolajewicz, M. Heimann and G. Hoffmann. 2000. Borehole versus isotope temperatures on Greenland: seasonality does matter. Geophys. Res. Lett., $27(5), 723-726$.

Wolff, E., I. Basile, J.-R. Petit and J. Schwander. 1999. Comparison of Holocene electrical records from Dome $\mathrm{C}$ and Vostok, Antarctica. Ann. Glaciol., 29, 89-93.

MS received 19 December 2002 and accepted in revised form 22 September 2003 